\title{
Handlingsplan mot selvmord: gode erfaringer skal føres videre
}

Ved Lars M ehlum og N ils Petter R einholdt

H andlingplan mot selvmord ble avsluttet ved årsskiftet 1999/2000. Selv om mye ble oppnådd gjennom årene med denne planen, gjenstår det mange utfordrende oppgaver. $\mathrm{N}$ år man skal ta fatt på disse oppgavene, står likevel landet langt bedre faglig rustet nå enn tidligere. I denne artikkelen omtales de sentrale målsettingene i oppfølgingsprosjektet til handlingsplanen "Tiltak mot selvmord 2000-2002".

H ovedkonklusjonene fra denne evalueringen er omtalt i tidsskriftet "Suicidologi" nr. 3/2000, og innebar i korte trekk at i det alt vesentlige hadde handlingsplanen innfridd forventningene som var stilt til den. $M$ en det har vært bred enighet om at det fortsatt står mange uløste oppgaver foran oss, og at det er fortsatt behov for en nasjonal strategi for selvmordsforebygging. På dette grunnlag har $\mathrm{H}$ elsetilsynet siden høsten 1998, som faglig ansvarlig myndighet på oppdrag fra H else- og Sosialdepartementet, arbeidet med ulike forslag til videreføring av ønskelige aktiviteter etter avsluttet prosjektperiode. $\mathrm{H}$ vilke konkrete erfaringer fra den første handlingsplanen er det man nå ser for seg skal videreføres og satses ytterligere på?

\section{Kunnskaper må skapes og formidles}

$\mathrm{H}$ andlingsplanen mot sel vmord rettet seg primært mot tiltak som skulle gi et bedre tilbud til grupper med spesiell risiko for selvmord. Sentrale virkemidler for å nå denne hovedmål settingen var bl.a. å innhente nye kunnskaper gjennom forskning, formidle kunnskap gjennom utdanning og informasjonsvirksomhet, og gi råd og veiledning til faggrupper som arbeider med kliniske og forebyggende prosjekter. En innså tidlig at en slik vektleggingav kunnskapsproduksjon og kunnskapsformidling gjorde det nødvendig med oppbygging av ressurssentra, og derfor ble det etablert fire små sentra ved universitetene. Etter hvert fikk sentrene noe ulik profil og forankring. Seksjon for selvmordsforskning og -forebygging (SSFF) ved U niversitetet i 0 slo fikk, som det største senteret, nasjonalt koordinerende oppgaver, men personellet ved alle fire sentre skulle samarbeide tett om en rekke oppgaver og utgjøre et samlet nasjonalt kompetansenettverk. I ettertid er det lett å se at disse fagmiljøene har spilt en nøkkelrolle for mye av det andre som ellers har skjedd i handlingsplanens regi. Ved hjelp av de små sentrene (til sammen dreier det seg faktisk ikke om mer enn 9 stillinger) fikk vi etablert faglige plattformer som mye annet kunne bygges på. I flere land vi naturlig kan sammenlikne oss med, som f.eks Sverige og Finland, har man ikke hatt noen tilvarende satsing på ressurssentre. I N orge har vi vært i den heldige stilling at vi har faste ressursgrupper som kan påta seg utviklingsoppgaver og bygge sin kunnskapsformidling på egen forskning, slik at landet til stadighet vedlikeholder suicidologisk spisskompetanse. I St. prp. nr 1 1998-99 som omhandlet videreoppfølging av den selvmordsforebyggende satsingen i N orge står det: "D epartementet tar sikte på å videreføre de etablerte ressursmiljøene som er opprettet ved universitetene utover handlingsplanens prosjektperiode". Ut fra det som hittil er nevnt, er vi svært glade for at våre politikere har sett nytten og betydningen av kompetansesentrene i suicidologi.

\section{Kontinuitet og kvalitet i oppfølging av risikoutsatte grupper}

$\mathrm{H}$ andlingsplan mot selvmord brukte en betydelig andel av sine budsjettmidler til å stimulere til opprettelse av behandlingskjedetiltak for selvmordsforsøkere ved en rekke av landets somatiske sykehus. Disse prosjektene har stort sett fått positive evalueringer og har skapt gunstige ringvirkninger i sine lokalmiljø (evalueringsrapportene kan lånes ved SSFF). En landsdekkende studie utført ved SSFF vinteren 1999/2000 understreker også betydningen av et strukturert samarbeid mellom sykehus og primærkommuner for kvaliteten på oppfølgingsarbeidet rettet mot selvmordsforsøkere ( $M$ ork $\&$ Ekeid 2000). Vektleggingen av denne type arbeid er et annet særtrekk ved den norske strategien for sel vmordsforebygging.

I N orge bygger vi nok i mindre grad enn i mange andre land på sykehusbaserte ressurser i klinisk oppfølging av selvmords-

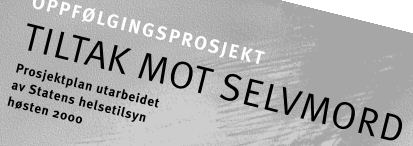

forsøkere,

og noen ville hevde at

vi benytter for lite sykehusressurser på denne gruppen. M en dette må også ses som en konsekvens av vårt særegne og desen-traliserte bosettingsmønster. Behandlingskjedetiltakene er godt tilpasset den norske kliniske hverdagen. Da det ble forslått en videreføring av aktiviteter etter handlingsplanens slutt, ble derfor en ytterligere innsats for å sikre gode behandlings- og oppfølgingsrutiner for mennesker innlagt etter selvmordsforsøk understreket. Dette arbeidet skal altså videreføres, og det er klart at ansvaret for oppbyggingen ligger i det enkelte sykehus i samarbeid med kommunene som sogner til sykehuset. M en ressurssentrene kan gjøre mye for å gi faglig bistand og veiledning i oppbyggingen av de nye tiltakene.

\section{Nye risikogrupper}

I løpet av de senere år har ny forskning, erfaring fra praksisfeltet og den generelle samfunnsutviklingen avdekket nye problemfelt der det er behov for en selvmordsforebyggende innsats. En av de gruppene som vi ser trenger mer bistand og støtte, er etterlatte ved selvmord. G ruppen har

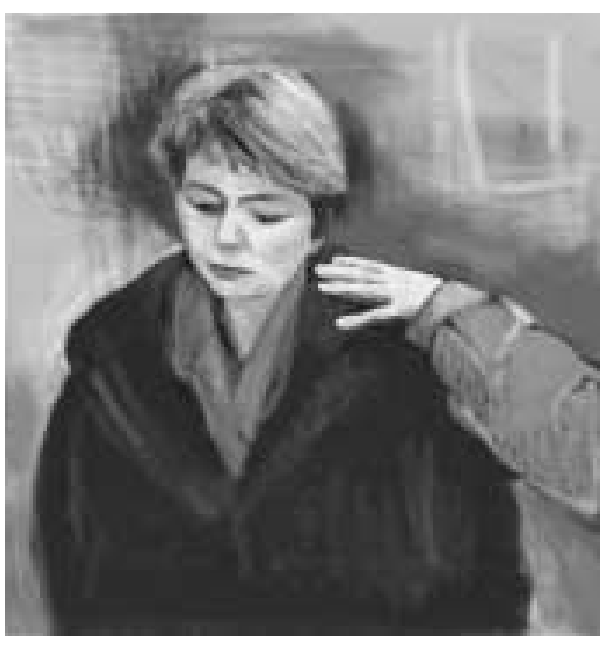


vært der hele tiden, men tabuer og fortielse gjorde det vanskelig for de fleste å stå frem med sine problemer. Etter hvert som tabuene og tausheten om selvmord har blitt redusert, har vi også blitt mer oppmerksomme på de etterlattes si tuasjon og behov. Følgelig har vi også fătt ambisjoner om en styrket forebyggende innsats. I kke minst er også de etterlatte selv en viktig ressurs. Derfor vil det de nærmeste årene bli satset mye på videre oppbygging og støtte til den nye Landsforeningen for etterlatte ved selvmord (LEVE), som nå har kommet godt i gang.

$\mathrm{H}$ omofile og lesbiske og deres problemer har hittil også vært sterkt undertrykket og fortiet. M en i de senere år har vi på dette området fått mer åpenhet, samtidig som økt forskning skaper bedre innsikt i problemer og behov. Selvmordsproblematikken blant unge homofile og lesbiske er en viktig utfordring. I oppfølgingsprosjektet "Tiltak mot selvmord" er derfor dette pekt ut som et viktig innsatsområde.

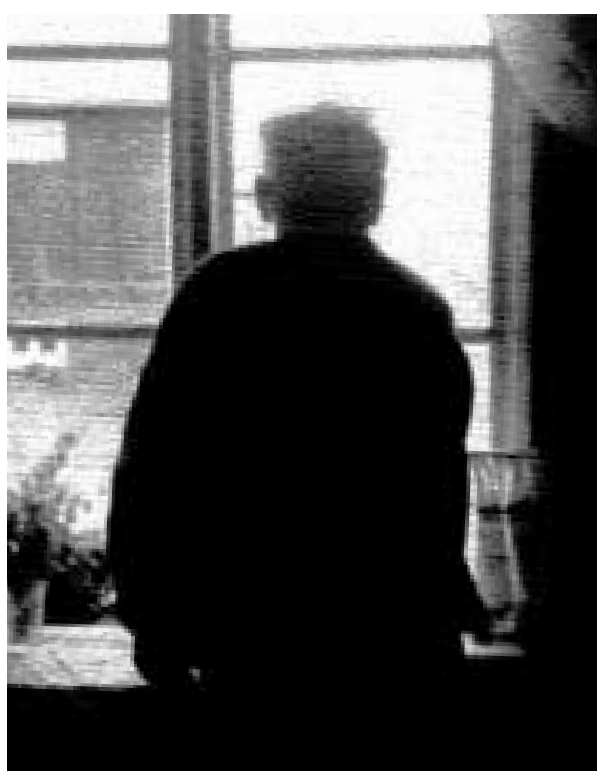

Eldre mennesker, særlig gamle menn, har relativt høye selvmordsrater i vårt land. Eldres selvmord henger ofte sammen med eksistensielle problemer knyttet til aldringen, tap av goder, relasjoner og funksjoner, samt en rekke psykiske vansker og rusmisbruk som ofte er sekundære til negative livshen delser. Forebygging av selvmord blant eldre kan ut fra det som her er nevnt, vise seg å være krevende og vanskelig fordi det kan medføre behov for holdningsendringer i samfunnet og endringer i vår måte å dra omsorg for eldre på. En beslektet problemstilling er selvmordsforebygging blant unge. Både for unge og eldre handler selvmordsforebygging om så vel spesifikke og avgrensende tiltak, slik som for eksempel styrkede behandlingstilbud for psykiske lidelser, som endringer i forhold ved sam-funnsutviklingen. I oppfølgingen av $\mathrm{H}$ andlingsplan mot selvmord vil en søke frem til noen svar og løsninger på disse vanskelige, men viktige utfordringene.

\section{Nye arenaer for forebygging}

Etter hvert har vi fått mer erfaringer med arbeidsplassrelaterte problemer og utfordringer som henger sammen med selvmordrisiko hos enkeltpersoner. $\mathrm{N}$ ye forskningsprosjekter har avdekket risikoforhold knyttet til visse yrkesgrupper og forskning opp mot omstillingsprosesser og arbeidsmiljø er på vei. D et er således skapt et bedre grunnlag for å velge blant mulige forebyggende tiltak. Dette vil det bli arbeidet mer med i årene som kommer.

I H andlingsplan mot selvmord 1994-99 var det ikke prioritert å satse nevneverdig på forebygging av selvmord gjennom fysiske eller juridiske begrensninger til tilgang til selvmordsmidler, slik som f. eks å utvirke endringer i regler for våpen besittelse og oppbevaring. I et land som $\mathrm{N}$ orge der en meget høyt andel av hjemmene har et skytevåpen, og der eksempelvis mer enn halvparten av alle unge menn som tar sitt liv, benytter skytevåpen, ligger det et stort forebyggingspotensiale i à begrense tilgangen til skytevåpen. A ndre tiltak kan dreie seg om endringer i medikamentforskrivningspraksis eller fysisk sikring av broer eller høye bygninger og steder. I andre land har slike tiltak vist seg å ha en netto selvmordsforebyggende effekt. Det vil bli arbeidet mer med denne skadeforebyggende tilnærmingen til selvmordsforebygging i tiden fremover.

\section{Nye utdanningstiltak}

$\mathrm{H}$ andlingsplan mot selvmord har hatt sin egen utdanningsstrategi, og mye godt arbeid ble utført på dette innsatsområdet gjennom handlingsplanperioden. D ette vil bli videreført. I tillegg er det besluttet å satse på to nye landsdekkende utdanningsprosjekter. Det ene prosjektet dreier seg om etablering av et toårig deltids videreutdanningstilbud i selvmordsforebyggende arbeid ved U niversitetet i O slo med studenter fra hele landet. I skrivende stund er studieplanen for denne utdanningen endelig godkjent, og de første studentene vil bli tatt opp høsten 2001. M ed denne utdanningen ønsker vi å gå i dybden og utdanne personell som skal besitte omfattende suicidologiske kunnskaper, og som derfor vil bli lokale ressurspersoner med evne til å igangsette og drive forebyggingsprosjekter, undervise og gi veiledning. Det andre utdanningsprosjektet, opplæringsprogrammet V IVAT, som inntil 1999 ble drevet som et regionalt prosjekt i N ord N orge, inkluderes nå som en del av den nasjonale formidlingsstrategien. H ovedformålet med dette programmet er å gi fagpersoner med ulik bakgrunn kunnskaper og ferdigheter slik at de bedre kan hjel pe mennesker i akutte selvmordskriser. I løpet av prosjektperioden legges det opp til en landsomfattende spredning av kurset "Førstehjelp ved selvmordsfare". På denne måten sikres vi bredden, utbredelsen av enkel kunnskap om hva alle kan gjøre for å hindre selvmord.

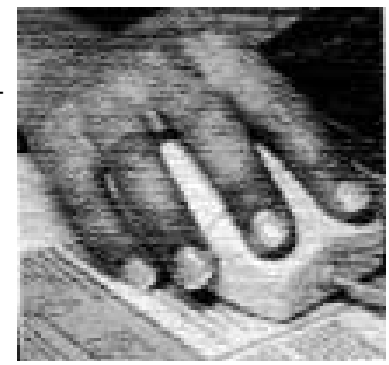

\section{Informasjons- og nettverksarbeid er fortsatt viktig}

Plandokumentet for $\mathrm{H}$ andlingsplan mot selvmord 1994-99 inneholder ikke mye om betydningen av en offensiv informasjonsstrategi. I midlertid innså man særlig ved SSFF at informasjonsarbeidet måtte prioriteres høyt, og flere prosjekter med dette som mål ble igangsatt; Suicidologi er ett av dem. Denne delen av handlingsplanprosjektet er da også blitt meget gunstig evaluert i A gendas rapport. Informasjonsarbeidet skal derfor videreføres regionalt og nasjonalt blant annet gjennom fortsatt utgivelse av Suicidologi. Et av de betydeligste resultater av $\mathrm{H}$ andlingsplan mot selvmord var den landsomfattende tilveksten av engasjerte fagpersoner involvert i selvmordsforebyggende arbeid. For å stimulere dette engasjementet øremerkes midler til videreføring av regionale nettverkssamlinger for ulike aktører på den selvmordsforebyggende arena. 


\section{Helsetilsynet er fortsatt engasjert i den selvmordsforebyggende strategien}

O ppføl gingsprosjektet "Tiltak mot selvmord" er som tidligere blitt forankret i

Statens hel setilsyn, A vdeling for spesialisthelsetjeneste. I handlingsplanperioden 1994-99 høstet man verdifulle erfaringer med denne styringsmodellen og etter hvert har den sentralt koordinerende funksjonen i $\mathrm{H}$ elsetilsynet fungert stadig bedre på mange vis. For fagmiljøene oppfattes det som viktig at $\mathrm{H}$ el setilsynet holder sin hånd over dette tiltaket som er så viktig i et folkehelseperspektiv i vår tid. H elsetilsynet har ansatt en egen prosjektleder i deltidsstilling, styringsgruppen videreføres med sammensetning som under $\mathrm{H}$ andlingsplan mot selvmord og det er oppnevnt en ny referansegruppe for prosjektet. For nærmere detaljer om organiseringen henvises det til prosjektbeskrivelsen: "O ppfølgings-prosjekt - "Tiltak mot selvmord 2000-2002".

\section{Konklusjon}

Som man vil forstå, er det altså virkelig mange nye og utfordrende oppgaver som ligger framfor oss i forebygging av selvmord, til tross for at mye alt er blitt gjort gjennom $\mathrm{H}$ andlingsplan mot selvmord 1994-99. Vi mener at landet nå står langt bedre rustet til en slik nysatsning enn da vi i sin tid startet arbeidet med den nasjonale strategien for selvmordsforebygging. Likevel er det fortsatt behov for nye hender og for mennesker som ønsker å bruke sin kreativitet og innsatsvilje på ett eller flere av de områdene som vi her har nevnt.

\section{Referanser}

A genda $U$ tvikling \& $U$ tredning. Evaluering av $H$ andlingsplan mot selvmord. Sandvika 2000

$\mathrm{H}$ andlingsplan mot selvmord. Sluttrapport. IK2720. 0 slo: Staten s helsetilsyn, 2000 (Skriftserie 3-2000)

O ppfølgingsprosjekt "Tiltak mot selvmord": prosjektplan utarbeidet av Statens helsetilsyn.

-Suicidol ogi 2000 ; 5 (Supplement)
M ork, Erlend \& Ekeid, G unnar. Psykososial oppfølging etter parasuicid: rutiner og praksis ved medisinske akuttavdelinger i N orge. H ovedoppgave i psykologi. O slo: U niversitetet i O slo, Psykologisk institutt, 2000.

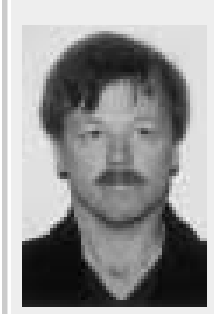

Lars Mehlum

er psykiater og professor i suicidologi ved U niv. i 0 slo. $\mathrm{H}$ an er leder for SSFF og er bredt engasjert i en rekke forsknings- og forebyggingsprosjekter. $\mathrm{H}$ an har publisert flere lærebøker, samt en rekke vitenskapelige artikler.

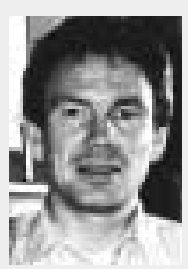
N ils Petter R einholdt er nasjonal prosjektleder i $\mathrm{H}$ andlingsplan mot selvmord og ansatt i $\mathrm{H}$ el setilsynet. $\mathrm{H}$ an er psykiatrisk sykepleier og ledet et lokalt handlingsplanprosjekt i 0 ppland fylke 1.1.95-1.1.98.

\section{Videreutdanningen i selvmordsforbyggende arbeid: flere skritt naermere studiestart!}

I løpet av januar og februar 2001 har "Forslag til studieplan for videreutdanning i selvmordsforebyggende arbeid" vært til behandling i Instituttgruppe for psykiatri og fakultetsstyret ved Det medisinske fakultet ved U niversitetet i O slo (U iO). Begge styrer ga sin tilslutning til opprettelsen av studiet. Vi er med andre ord kommet viktige skritt videre på veien mot etablering av utdanningen som en del av U iO . Vi håper å være i gang med studiet i løpet av høstsemesteret. Før den tid skal imidlertid planen ut på høringsrunde og Kollegiet skal behandle saken. Vi vil gjennomføre dette samtidig som vi forbereder studiestart.

Studieplanen legger opp til et 20 vekttalls studium på deltid over to år. Det vil bli to samlinger per semester, hver av en ukes varighet. M ellom disse legges det opp til regionale samlinger i veiledningsgrupper. I studiets siste år skal det skrives en pro-sjektoppgave. Denne kan utarbeides individuelt eller i gruppe. U niversitetets program for nettbasert undervisning "C lassfronter" vil bli tatt i bruk for at studenter, administrasjon og undervisere kan ha kontakt med hverandre underveis i studiet. Programmet gjør det mulig f.eks. å skrive oppgaver sammen selv om man bor på forskjellige steder av landet. Timeplaner, forelesninger og studieoppgaver vil også kunne finnes her. Det forutsettes kunnskap om og tilgang til Internett.

U tdanningens hovedhensikt er i studieplanen gitt føl gende formulering: Kandidatene som gjennomfører studiet, skal ha kompetanse til å planlegge, iverksette, koordinere og evaluere selvmordsforebyggende virksomhet både lokalt og regionalt. A $v$ de viktigste innholdskomponenter kan nevnes: epidemiologi, forståelse av selvmord og selvmordsatferd, risikofaktorer, forebyggende modeller og teorier, intervensjon knyttet til utsatte grupper/ personer, sel vforståel se hos hjel pepersonellet, etiske utfordringer, forskning, fagutvikling og formidling, samt offentlige dokumenter og lovverk.

Studiet er et videreutdanningstilbud til personer som har fullført høyere helseog/eller sosialfaglig utdanning av mini- mum 3 års varighet. Det er en klar fordel om søkerne har yrkesmessig erfaring i å arbeide med mennesker som enten har hatt tanker om å ta sitt liv eller har gjort selvmordsforsøk. A ndre søkere som arbeider med selvmordsproblematikk og som har relevant utdanning, kan også vurderes for opptak. U tdanningen er planlagt under forutsetning av at den $\mathrm{i}$ hovedsak skal være selvfinansierende. Det betyr at vi må ta en deltakeravgift av den enkelte student. Det er Kollegiet som fastsetter avgiftens størrelse. Vi planlegger opptak av 24 studenter. Studieplanen og annen relevant informasjon vil fortløpende bli lagt ut på SSFFs I nternettsider (http://www.med.uio.no/ipsy/ssff).

Ytterligere opplysninger kan fåes ved henven delse til undervisningskonsulent Dag W illy Tallaksen, enten per e-post: d.w.tallaksen@psykiatri.uio.no eller telefon: 22923473.

D ag Willy Tallaksen, undervisningskonsulent ved SSFF. 